CORRESPONDENCE

\title{
ROGER BACON AND PHILIP DE COLUMBIERS
}

To the Editor of The British Journal of Ophthalmology.

SIR,-In my article on the father of British optics in the BRITISH Journal of Ophthalmology (Vol. XII, p. 3) there is a footnote drawing attention to a statement that Roger Bacon was set down in a plea roll of Henry II as brother to Philip de Columbiers; and it was hinted that this must be a mistake for Henry III, as Bacon had not been born at the time of the death of Henry II.

I am now in a position to clear the matter up. In Round's Calendar of Documents preserved in France, illustrative of the History of Greal Britain and Ireland (1899), I find among the charters of the abbey "des (Dames) Blanches" at Mortain, an abstract of a charter of Henry II, dated circ. 1174. In it the King confirms to the nuns of Mortain twenty-five sestiers of wheat which Roger Bacun gave them in alms for ever, with the consent of Philip de Columbiers, his brother.

A charter of Henry II to the Priory of St. Stephen, PlessisGrimould, shows Roger Bacon making his peace with Philip, Bishop of Bayeux, for the death of Beatrice, his niece; here again he is set down as brother to Philip de Columbiers. The date of this deed is 1156-1162. In another deed, dated 1170-1175, I find Roger Bacon acting as a witness to a royal charter granted to the same priory.

There can be no doubt of the correctness of the statement, but it does not follow that Roger Bacon, the father of British optics, was in any way connected with the Roger of these deeds. He certainly belongs to a later generation.

Yours truly,

R. R. JAMES.

\section{NOTES}

WE regret to record the death at Johannesburg

Death of $\mathrm{M}$. Baranov, a promising young colonial ophthalmic surgeon. He had been housesurgeon at University College Hospital, and senior house-surgeon at the Royal London Ophthalmic Hospital. He had been at work 